\title{
A Scientific Examination of and Report on the Hungarian Cartel Law in the Framework of the Bolyai Scbolarship
}

Keywords: Hungarian Cartel Law, Bolyai Scholarship, report

Słowa kluczowe: węgierskie prawo antykartelowe, Bolyai Stypendium, raport

The historical examination of cartel law is the topic of the János Bolyai Research Scholarship (BO/00198/18/9) and the science-propagating New National Excellence Program of the Ministry of Human Capacities ${ }^{1}$ that disseminates it. Within its framework, professional activities that introduce and popularize new research and scientific results, took place during the first semester of the 2018/2019 session.

During my research, I tackled the examination of historical changes in cartel law during the first half of the $20^{\text {th }}$ century from an international perspective. It was during this time period that the $20^{\text {th }}$ Act of the year 1931 on agreements regulating free trade was codified, which regulated the formation and operation of cartels. After World War I, economic and social changes affected legal development as well, and as a result, national interference and participation became more significant in the field of private law, taking fair trade and consumer interests into account. This proved to be especially justified when cartels were taken into account, and on a surface level this was reflected in the establishment and regulation of cartel supervision authorities. In the current period of the research, the collection and analysis of the primary and secondary sources has already begun. Discovering and analysing the remaining archival sources in connection to legislation and legal practices is what gives true depth to any research in the field of legal history.

Adherence to the conventions of the Szeged School of Legal History provided the primary purpose and the underpinnings of the research. However the examination of 
materials of the supervising authorities, the Cartel Court and the Cartel Committee, met with the problem that a significant amount of archival sources located in the files of the Hungarian National Archives was destroyed as the result of a bombing-induced fire in 1956. However, a fragment of the records of the Cartel Court was successfully located.

The description of the research methodology took place during a talent-nurturing program organized by the Department of Hungarian Legal History on $1^{\text {st }}$ October, 2018, where my objective was to describe archival source analysis through a specific legal case, thereby drawing attention to the aspect of what a researcher may be able to reconstruct via remaining verdicts. The lawsuit of the Lime- and Fake Mortar Sales Public Limited Company and merchant Ferenc Wittman from 1933 (P. 56341/1933/3) can be found in the Budapest City Archives of the Hungarian National Archives, and this served as the basis of methodological analysis. Based on the verdict of the Royal Court of Justice, Budapest, the practical enforcement of formal legal regulations can be reconstructed perfectly, via the mutual agreement of the participants regulating economic competition.

However, the operation of the Cartel Court can be examined through the analysis of the leading cases, these works significantly aided the standardization of cartel law. My investigations in this area greatly helped in the understanding of the concept of the public interest lawsuit, and in connection with this, my investigations in this area will be published as a study (Lawsuits of Public Interest in Cartel Law). I also held a lecture entitled Excerpts from the Practices of the Cartel Court on $14^{\text {th }}$ December, 2018 during the NNEP conference entitled Political and Legal Science without Borders. By means of this lecture, I greatly emphasized the economic and legal interests, and the role and practices of the Cartel Court, not to mention the possible threats that were caused by the separation of powers, and arose in connection with the secretary's lawsuit filed against cartels that endangered the guaranteed principle of judicial sovereignty, behind the introduction of public interest lawsuits. The practices of the Cartel Court could be seen through the leading cases, not to mention the matters of contract validity, and the definition of the concept of cartel arose in connection to substantive law.

The other thing the research was based upon was the analysis of professional literature, to examine the significant role that the contemporary legal practitioners of that era had in criticizing the so-called "Cartel Procedure Law". Even during Parliamentary debates, legal concerns arose on the matter of regulation, especially the enforcement of cartel contract presentation, the delegated powers of supervising authorities, and the introduction of public interest lawsuits. This is closely connected to the central and also fundamental question of what to regulate: cartel public interests or cartel private laws. The regulations of the act are fundamentally within the framework of public interests, therefore the regulations of cartel private law are defined by the general rules and basic principles of private law. In the secondary professional literary sources, apart from the generally positivistic descriptions of law articles, several authors (for example, Károly Dobrovics, Nándor Baumgarten, Artur Meszlényi, Ferenc Harasztosi Király, Nándor Ranschburg) not only describe the dogmatic background of the topic, but also its connections in the field of economic history, before moving on to the description of cartel substantive law and cartel case law.

During the series of events entitled Researchers' Night (28 ${ }^{\text {th }}$ September, 2018), the Department of Hungarian Legal History organised a series of presentations under the 
name Past and Present Investigations in Legal History where I gave a presentation entitled The Effect of World War I on Economy and Law with the objective of describing the connections between the World War, economy and law, and the shifts that happened in every sector of society, which all affected the regulation of cartels. The social tension (for example, scarcity of food and raw materials, unemployment, shop-shortages, and debts), which was the result of the Great Depression, mostly manifested itself as the drastic price-rise of commodity-like products. The state decided that it was necessary to "limit" and regulate the formation of cartels via legal methods.

In order to comprehend the formation of the Cartel Procedure Law, it is necessary to introduce the codification antecedents of the research topic. The first step towards this was the $15^{\text {th }}$ Act of 1920 that regulated illegitimate over-pricing misconduct. This was followed by the precursor of the Cartel Procedure Law, in the form of the $5^{\text {th }}$ Act of 1923 that regulated unfair competitive actions. As the closing act of the codification process, the Cartel Procedure Law finally came to fruition in an era when several European nations (for example, Germany) regulated cartels. I previously presented the history of the codification of the Cartel Procedure Law of Hungary during an international conference organised by the West University of Timisoara on $2^{\text {nd }}$ November, 2018. In my presentation (The Codification of the Cartel Procedure Law in 1931) I focused my attention on the economic and social background of the regulation of the cartel law of Hungary.

An important segment of the dissemination of the research was to make the topic more available for undergraduate students. The elective course The History of the Cartel Law serves this purpose for any undergraduates who are interested in the national and international precursors of the regulation of cartel law, not to mention the examination of the practical formation of the Cartel Procedure Law through the analysis of legal precedents.

The research of the history of cartel law based mainly on archival sources, offers researchers the opportunity to gain insight into actual practical applications, and therefore get a more complete understanding of how the operation of cartels were significantly affected by contemporary social and economic circumstances. 